\title{
高齢者の歩行と転倒 一疫学的調査からー
}

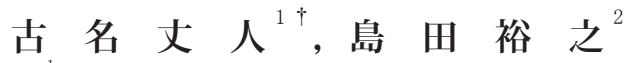 \\ ${ }^{1}$ 札幌医科大学 保健医療学部 \\ ${ }^{2}$ 東京都老人総合研究所 日本学術振興会特別研究員
}

要旨 平均寿命の延長と老化に伴う個人差の増大は, 運動学研究における決定論的な議論を困難にする. 一方, 疫学的な研究は 大規模な代表性ある集団を対象とすることが多く，高齢者の諸機能の特徵，平均像を同定することができる.

本稿では, まず, 高齢者の運動機能研究における疫学的視点の必要性を述べ, 長期縦断研究の結果から高齢者の歩行機能の 加齢変化を提示した上で, 健康や寿命との関わりについて概説する. さらに, 運動学やバイオメカニクスと疫学の共通の課題とな る転倒に焦点をあて, 学際的な研究によってこれらの問題が解決できる可能性について述べる.

キーワード : 高齢者, 疫学, 歩行, 転倒

\section{1.はじめに}

疫学とは,「地域や特定の集団内で疾患や健康に関する事 象の発生の原因や変動する様を明らかにする学問」である. 人類の定義の一つである歩行（直立二足歩行）と疫学は, 歩 行機能の老化, そして挖々らくれによって起こる健康上の問 題, この二点で両者は接点を持てる. というより, 老年学とい う学際的な分野を経由して関係がある.

さて, 高齢者歩行 (研究) と言えば真つ先に Murray ${ }^{1)}$ の図 を思い起こす諸兄も多いだろう。描かれた典型的な高齢者像 からは, 体幹の前傾, 手足の軽度屈曲, そして最も象徵的で ある歩幅の減少，が高齢者歩行の特徵として読み取れる.「高 齢者」とは 65 歳以上を指すものであるが（国際連合，1982）, Murray の時代, すなわち 1970 年前後のアメリカの平均寿命は, 男性 67 歳, 女性が 75 歳程度であり現在よりその対象は少な く, 高齢者は非常に特異的な存在であったと伺い知れる. 現 在, 世界の先進国寿命は飛躍的に延伸し, 本邦の平均寿命を 見ると男性 78 歳, 女性 86 歳となり,「高齢者」の範囲も拡大 の一途とたどっていて, Murrayの示した「高齢者歩行」が現 在でも当てはまる保証はない.

一方, 近年の高齢化社会の到来により, 高齢者の生活機能 と歩行機能の関連がトピックスになっており, 生活機能の低下 を来たし介護が必要となる状態を招聘するリスク, それらは虚 弱, 転倒・骨折などの老年症候群 ${ }^{2)}$ と呼ばれるものであるが, その発生予防（介護予防）の文脈で歩行の重要性が再認識さ れているといって過言ではない。

\footnotetext{
2006 年 7 月 11 日受付

${ }^{\dagger} \bar{\top}$ 060-8556 札幌市中央区南 3 条西 17

札幌医科大学 保健医療学部

古名 丈人

Tel:011-611-2111 Fax:011-611-2150

E-mail:furuna@sapmed.ac.jp
}

上述した二つの問題は，“高齢者”という属性の問題と，そ れに伴う個人差の問題に集約することができる. 本稿では, 著 者が関わった大規模調査の経験から, まず高齢者の歩行にど のようにアプローチしていったかを示し, 高齢者における歩行 測定（計測）の意義を述べる. さらに, 高齢者歩行, またそ れに密接に関連する転倒に関して概説する.

\section{2. 疫学研究の必要性}

本邦女性の平均寿命は 85 歳を超え，世界一の水準を誇つ ている. 平均寿命は「0 歳児平均 “余命”」のことであり, たつ た今生まれた赤ん坊が, 平均的にどれくらい命を享受できるか という期待值のことである. 逆に, 高齢者は, 出産, 青少年 期の事故, 成人期の三大疾病のリスクから生ずる死を免れて いるので, 高齢者の余命を現在の年齢に加えると, 全体とし ての寿命は平均年齢をはるかに超える. 例えば, 65 歳女性の 余命は 22 歳であるので, 現在の 65 歳に到達している高齢者 の半数は 88 歳に到達できることを意味する. これは男性も同 様であり，「高齢者」を表す範囲は，一般的に知られている以 上に拡大しているわけである. 老年学では, 65 歳〜 74 歳を 前期高齢者， 75 歳以上を後期高齢者と区別し，さらに最近で は, 85 歳以上を超高齢者と呼び ${ }^{3)}$, 高齢者の範囲を分けて対 処している. 同時に, 諸機能の個人差は加齢とともに拡大す る ${ }^{4)}$ ので, 対象高齢者の年齢とともに機能的な状態(functional status)を明確にする必要がある.

一方, 過去の標準值などを参照する場合には, コホート効 果 (cohort effect) $)^{5)}$, つまりその時代の人々全てに共通する因 子の存在により, 諸機能の值が影響される可能性に注意しな ければならない（ちなみに, その時代の栄養状態, 栄養志 向により身長が影響されることがコホート効果として知られて (る).

以上のことは, 研究の標的集団が, 何歳のどのような機能 
状態の（あるいはどの時代の）高齢者対象としたものであるか によって, 結果が異なる可能性を含んでいることを示唆してい る.これが, 無作為抽出や悉皆調査による偏りのない大規模 集団を対象とする度学的な横断的・縦断的研究が必要とされ る所以である. このコホート効果などの可能性は, 運動やバイ オメカニズム研究にも存在することになる。一方, 詳細な実験 研究のような方法論を疫学研究において用いることは現実的 ではなく, 両者の知見を学際的レベルで情報交換を行うことが 重要ということになる.

\section{TMIG-LISA 研究における歩行測定}

東京都老人総合研究所中年からの老化予防総合的長期追跡 研究 (Tokyo Metropolitan Institute of Gerontology, Longitudinal Inter-disciplinary Study of Aging, TMIG-LISA) ${ }^{6)}$ は, 1991 年に 始まり, 現在もなお継続中の緃断研究である.この研究では, 当該地域に住民登録をしている高齢者の約 $80 \%$ が参加し（約 700 名：100 名/1日の健診数), 医学的健診, 運動機能検 查をはじめとする学際的な調査が行われてきた（図 1). 医学 的変数, 運動学的変数を入手し, それぞれの横断的・縦断的

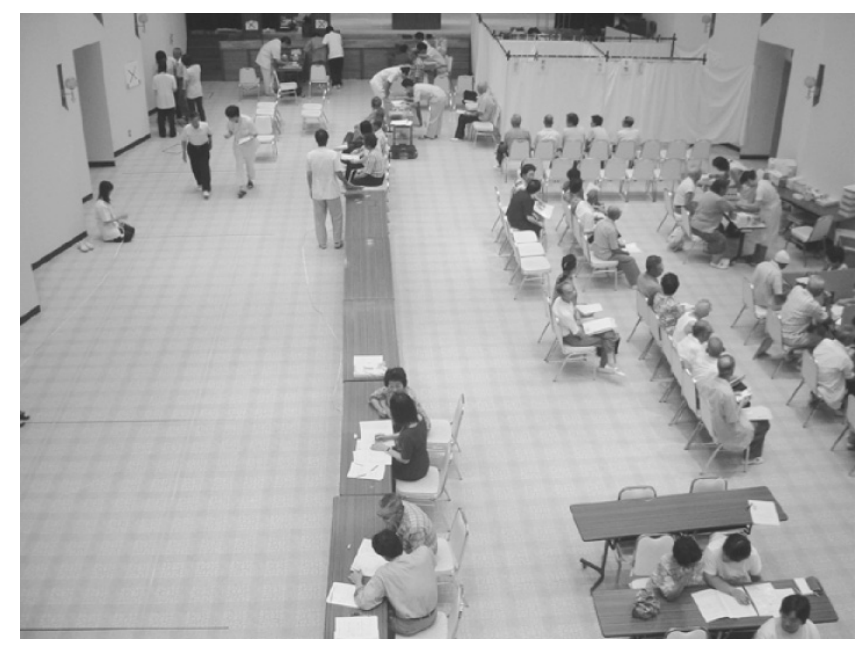

図 1 中年からの老化予防総合的長期追跡研究 TMIG-LISA の健診 風景運動検査は写真左の領域で実施されている

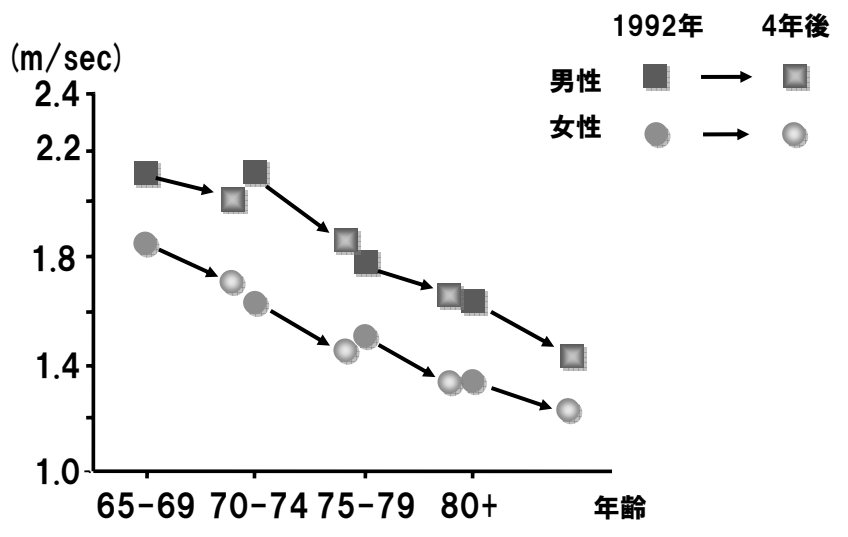

図 2 歩行機能（最大歩行速度）の加齢変化
加齢効果を確認するとともに, 将来の疾病や機能状態の低下 の予測因子を同定することが目的の一つであった．歩行測定 は運動機能テストの一環として行われ，歩幅，歩行率，歩行 速度の 3 変数を得た。な扔, 多くの大規模調査では歩行機能 をその測定項目に含んだとしても物理的な制約からストップウ オッチを使った時間計測（歩行速度の算出）のみが実施され るのがせいぜいであり，一方，本調査では時間測定者の他に 2 名の検者（距離測定）を加えただけで空間的指標も得られ る方法 ${ }^{7)}$ を採用していることが最大の特徴であると言える。 な おこの方法は三次元計測器を使用した平行測定により信頼性 が高いことが確認されている ${ }^{8)}$.

本研究による横断的加齢効果 $(\mathrm{N}=714)$ は, 歩幅, 歩行率, 歩行速度, 歩行比 (歩幅/歩行率) の全てが 65 歳以上で 減少するという加齢効果を認めたが ${ }^{9)}$, 形態による補正を施 すと歩行率の加齢効果は消失した. また， 4 年の縦断的加齢 効果では, 歩行率を除く全ての歩行変数に縦断的加齢効果 が認められた ${ }^{10,11)}$ 。すなわち, Murray ${ }^{1)}$, Elble ${ }^{12)}$, Wall ${ }^{13)} ら$ が報告しているように, 歩行速度の減少は歩幅の減少による ものであり, 歩行パターンが加齢により小刻みに変化したも のと言える. 4 年間の年代ごとの歩行速度では (図 2), 横 断的効果・縦断的効果はほぼ同様の変化を示し, この間で はコホート効果は認められない, しかしながら, 初回の調查 から 10 年経過した 2002 時点では, 平均值が 10 歳ほど若く シフトしたことが確認されて打り ${ }^{14)}$ ，これが栄養状態などによ る形態によるものか, あるいは歩行そのものが変化したのか を今後検討する余地がある。 なお，TMIG-LISA では，一度 VICONを現地にもちこみ，600 名を越える高齢者歩行時の 3-D データを取得している。この詳細ついては西澤論文 ${ }^{8)}$ 参照されたい。

また, （最大）歩行速度は, 運動機能バッテリーテスト全体 から定義される “運動能力”をもっとも代表する ${ }^{15)}$ ので, 多数 の種目が実施できない場合には，少なくとも歩行テストだけで も実施することを強く推奨する ${ }^{16)}$.

\section{4. 機能状態と歩行能力 - 老年症候群との関係一}

高齢者の機能状態の低下が進むと介護が必要な状態を招く 恐れがあり, その原因の第一位が脳血管疾患で, 以下（身体 的）虚弱，転倒・骨折，認知症，関節障害とつづく，これら 老年症候群は, 明らかな病気ではないこと, 症状が致命的で ないこと, 初期には日常生活への障害が小さいこと, などが特 徵とされている. 一方, 65 歳以上の死亡原因はガン, 心蔵病, 脳血管疾患であることの対比から，健康長寿を実現するため には，三大成人病の予防とともに老年症候群の予防が大切で ある. 高齢者数の増加にともない, 要介護者数の増加も見ら れているところであるが, 特に, 軽度要介護者がそれに至った 原因は，重度者に比べて老年症候群によることが多いこともわ かっている，高齢者自身の QOL を高めることはもとより，社 会的コストを小さくするためにも，これらの予防策を確立するこ とが急務である ${ }^{2)}$. 
高齢者を対象にした大規模縦断研究の目的の一つは, 機 能的状態や生活機能の低下要因の同定であるとすでに述べた. 地域在住高齢者を対象にした複数の縦断的研究によると, そ の調査期間の長短はあるものの, ベースラインの運動機能, と りわけ歩行速度が, 機能的状態を決定する有力な予測因子で あり ${ }^{11,16,17)} .14$ 年におよぶ長期縦断研究においても, 初期の 運動機能は（歩行速度）は将来の機能的状態を左右するとし ている ${ }^{18)}$. また, 神経学的問題による歩行異常を有するか否 かにより, その後の施設入所や死亡リスクが異なるという報告 19) もある. このように歩行は老化の影響を調べる対象であると 同時に，高齢者においては将来の健康や寿命に影響を及ぼす “機能”としての大きな意味を有する.

\section{5. 転倒の弊害 一転倒の疫学一}

転倒は, 歩行, 姿勢との関係から運動学やバイオメカニズ 厶的な研究も多く, また, その予防方法を確立することも急務 であるため，ここでは少し詳しく触れることにする.

高齢者の $10 〜 40 \%$ は年間に転倒を経験し ${ }^{20)}$, しばしば 重篤な疾病や障害を引き起こす，転倒による疾病の内，骨折 は最も頻繁に生じ, 約 5\% の転倒が骨折に結びついている ${ }^{21)}$. この程度の外力によって成人に扔いては通常骨折は起こらな い. すなわち高齢者における骨の脆弱性が転倒による骨折を 引き起こす背景となっており, 高齢者全体の約 $1 / 3$ に相当する 骨粗鬆症患者は骨折予備軍であると言われている ${ }^{22)}$.

骨折の中で, 特に大腿骨頸部骨折は治癒に長い期間を要し, 安静臥床中に体力の低下を来し寝たきりになる確率は高く, こ の骨折は 60 歳以降急増する ${ }^{23)}$. この傾向は欧米に扔いても 同様であり, 大腿骨骨折を受傷した $90 \%$ 以上の症例が転倒に より骨折を引き起こしている ${ }^{24)}$.

大腿骨頸部内側骨折により入院した高齢者の縦断的歩行機 能調查 ${ }^{25-28}$ では, 骨折前に歩行可能であった患者のうち 16 〜 33\%の高齢者が退院時に歩行不能となったとされている. これは長期臥床を強いた結果に生じた体力の低下が, 高齢者 にとっては不可逆的になり得るものであるということを示して いる. また, 大腿骨骨折後の 1 年間は受傷者の死亡率は高く なる ${ }^{29)}$. さらに, 米国の調査によると, 85 歳以上の高齢者に おいて大腿骨頸部骨折により入院後, 家庭復帰できる割合は, わずか $6.6 \%$ であり, 他の骨折や外傷における $50 \%$ 以上の復 帰率と比較すると，施設入所や死亡といった転帰をとる率が非 常に高いことも特徴といえる ${ }^{30)}$. さらに, 転倒による死亡者数 も年々上昇し, 特に 70 歳以上の高齢者では, 死亡者数が急 激に上昇する ${ }^{31-33)}$.

このように転倒によって骨折や死亡といった重篤な傷害を来 す場合もあるが，その他の多くの転倒者は重篤な身体的傷害 を受けない. しかしこのような転倒者においても, 転倒後の自 信の喪失や転倒への恐怖感から活動性が低下する転倒後症候 群により, 長期的には機能低下が起こり得る ${ }^{34)}$. 従って, この ような重篤な疾病や活動性の低下から ADL 低下を来し, 時に 死亡原因ともなる転倒の予防は急務の課題であるといえる.

\section{6. 転倒の危険因子}

転倒を予防するためにはその原因の究明が必須である. 現 在までに様々な転倒の危険因子が明らかにされている. 身体 機能に関連した転倒の危険因子は感覚障害 ${ }^{35}$, 反応時間の遅 延 ${ }^{36)}$, 筋力低下 ${ }^{377}$, バランス機能低下 ${ }^{38,39)}$, 歩行機能低下 ${ }^{40)}$, 起居動作能力の低下 ${ }^{41)}$ などが挙げられる. その中でもバラン スや歩行機能低下は転倒の主要因であり, これらの障害を有 する高齢者は $1.6 〜 5.4$ 倍の転倒の危険を有する ${ }^{42)}$.

また，ほとんどの転倒は歩行中につまずいたり，滑ったりす るような急激な外乱刺激により発生する ${ }^{43)}$. 滑つたりつまずい たりした時に転倒を防ぐためには, 外的な刺激に対する急速 な立ち直り反応とステッピングが要求される. 立位時の外乱刺 激に対する立ち直り反応は, 四肢や体幹の協調した働きによっ て成立し, 外乱が強くて姿勢保持が困難な場合（あるいはもっ と早い時点から）にステッピング反応が起こる. これらの反応 は視覚, 前庭覚, 体性感覚からの入力刺激を統合し, 適切な 筋出力を急速に起こす必要がある ${ }^{44-46)}$. これらの機能は加齢 により低下し ${ }^{47,48)}$, 高齢者の $10 \%$ から $25 \%$ はバランスや歩行 機能の低下により転倒を引き起こしている ${ }^{49)}$. 従って, 転倒者 のスクリーニングにはバランス機能の評価が重要であると結論 できる.

\section{7. バランス機能の評価と介入}

バランス機能の評価には, 重心動摇測定のような静的な状 態に抢ける重心の保持能力を観察する場合や, 筋電図, 動 作解析などにより外乱刺激時や運動時の評価が行われている. また, より実践的には, 機器を用いないさまざまな臨床測定 ツールを用いてバランス評価がなされている ${ }^{50)}$. 転倒とより強 く関連するバランス機能は, 外乱刺激や運動時の機能であり, この側面からの評価や介入が高齢者の転倒予防のために求め られる ${ }^{51,52)}$.

外乱刺激が加わった時に転倒を回避するためには, 外乱初 期の重心の偏倚を最小に抑えることが重要であり ${ }^{53)}$ ，そのた めには体幹の活動よりも早い下肢筋の活動が重要である ${ }^{54,55)}$. このような歩行中のバランス機能は立位でのバランス機能と必 ずしも相関が得られないため, 転倒予防のための詳細な評価 をするためには，立位バランス検査に加え歩行時のバランス 機能を測定する必要性が示唆されている ${ }^{56,57)}$. Tang ${ }^{55)} ら は$ 移 動式プラットフォームを用いて歩行中に滑り刺激を発生させて, そのときの筋電図を分析した，その結果，体幹筋よりも下肢 筋の反応が，外乱で崩れた姿勢を早く立ち直らせるために重 要であり, その中でも特に前脛骨筋や大腿直筋といった下肢 前面の筋の重要性を指摘している. そして若年健常成人と比 較し高齢者では筋の反応潜時が延長, 筋発火量が減少, 拮抗 筋の同時収縮時間の延長, バランスを保つための上肢の代償 的反応なざが観察され, 加齢に伴う外乱刺激に対する姿勢反 応の能力低下が明らかとされている ${ }^{58)}$. これらの知見は, 高 齢者の転倒予防のために歩行中に外乱刺激が生じたときのバ ランス機能の強化の必要性を示唆するものであり，このような 
側面からの介入が望まれる.

著者らは高齢者の転倒予防を目的としてトレッドミルを用い た外乱負荷歩行練習の介入研究を実施した ${ }^{59,60)}$. これらの研 究で外乱負荷を加えた歩行練習は高齢者の身体機能の向上に 寄与することが明らかとなっている. 今後は, 外乱負荷歩行に よる転倒予防に対する効果を検証していく必要がある.

\section{8. まとめ}

疫学的視点からみた高齢者歩行の加齢効果とそれが高齢者 の生活機能に及ぼす影響について述べた。 大規模な調査はそ の平均像を明らかにできるが，詳細なメカニズムについて立 ち入ることは困難である. 逆に, 実験室実験における結果の 一般化には限界がある. 運動やバイオメカニズムの実験室実 験と大規模調查研究の関係は, 言ってみれば “森と木” の関 係である. 上述した高齢者の歩行や運動機能に関係する諸問 題については, 実験室研究とフィールド（大規模）研究が融 合して初めてそれが解決してゆくのだろう。

\section{参考文献}

1) Murray, M.P., Kory, R.C. and Clarkson, B.H.: Waking patterns in healthy old men, J Gerontology, 24, 169-178, (1969).

2) 鈴木隆雄, 岩佐一, 吉田英世, 金憲経, 新名正弥, 胡 秀英, 新開省二, 熊谷修, 藤原佳典, 吉田祐子, 古名丈人, 杉浦美穂, 西澤哲, 渡辺修一郎, 湯川晴美: 地域高齢者 を対象とした要介護予防のための包括的健診 (「お達者 健診」）についての研究, 日本公衆衛生雑誌, 50, 39-48, (2003).

3) Spirduso, W.W.: Physical Dimensions of Aging, 7-8, Human Kinetics, (1995).

4) Nelson, E.A. and Dannefer, D.: Aged heterogeneity, fact of fiction? The fate of diversity in gerontological research, Gerontorogist, 32, 17-23, (1992).

5) 柴田博, 芳賀博, 長田久雄, 古谷野亘 (編) : 老年学入門, 3-10, 川島書店, (1993).

6) Suzuki, T. and Shibata, H.: An introduction of the Tokyo Metropolitan Institute of Gerontology Longitudinal Interdisciplinary Study of Aging (TMIG LISA, 1991-2001), Geriatr Geron Int, 3, S1-S4, (2003).

7) 古名丈人:加齢によって歩行はどうかわる?, 奈良勲 (編): 理学療法の捉え方, part2, 125-133, 文光堂, (2003).

8) 西澤哲, 長崎浩, 古名丈人, 奥住秀之, 杉浦美穂, 伊東元, 藤田祐樹：地域高齢者を対象にした歩行時のフットクリア ランスに関する研究，バイオメカニズム，14, (1998).

9) 古名丈人, 長崎浩, 伊東元, 橋詰謙, 衣笠隆, 丸山仁司: 都市および農村地域における高齢者運動能力, 日本体力 医学会雑誌, 44, 347-356, (1995).

10）杉浦美穂, 長崎浩, 古名丈人, 奥住秀之: 地域高齢者 の歩行能力 -4 年間の縦断変化一, 日本体力医学会雑誌, 47, 443-452, (1998).
11) Furuna, T., Nagasaki, H., Nishizawa, S., Sugiura, M., Okuzumi, H., Ito, H., Kinugasa, T., Hashizume, K. and Maruyama, H.: Longitudinal change in the physical performance of older adults in the community, J Jpn Phy Thra Assoc, 1, 1-5, (1998).

12) Elble, R.J., Sienko-Thomas, S., Higgings, C. and Colliver, J.: Stride-dependent changes in gait of older people, J Neurol, 238, 1-5, (1991).

13) Wall, J.C., Hogan, D.B., Turnbull, G.I. and Fox, R.A.: The kinematics of idiopatic gait disorder, A comparison with healthy young and elderly females, Scand J Rehabil, 23, 159-164, (1991).

14）鈴木隆雄, 權珍嬉：日本人高齢者における身体機能の縦 断的・横断的変化に関する研究一高齢者は若返っている か?一, 厚生の指標, 4, 1-10, (2006).

15) Nagasaki, H., Ito, H., and Furuna, T.: The structure underlying physical performance measures for older adults in the community, Aging Clin Exp Res, 7, 451-458, (1995).

16) Guralnik, J.M., Ferrucci, L., Pieper, C.F., Leveille, S.G., Markides, K.S., Ostir, G.V., Studenski, S., Berkman, L.F. and Wallance, R.B.: Lower extremity function and subsequent disability, Consistency across studies, predictive models, and value of gait speed alone compared with the short physical performance battery, J Gerontl, 55A, M221-231, (2000).

17) Suzuki, T., Yoshida, H., Kim, H., Yukawa, H., Sugiura, M., Furuna, T., Nishizawa, S., Kumagai, S., Shinkai, S., Ishizaki, T., Watanabe, S. and Shibata, H.: Walking speed as a good predictor for maintenance of I-ADL among the rural community elderly in Japan, A 5-year follow-up study from TMIG-LISA, Geriat Gerontol Int, S1-S4, (2003).

18) Brach, J.S., FitzGerald, S., Newman, A.B., Kelsey, S., Kuller, L., VanSwearingen, J.M. and Kriska, A.M.: Physical activity and functional status in community-dwelling older women, a 14-year prospective study, Arch Intern Med, 24, 2565-71, (2003).

19) Verghese, J., LeValley, A., Hall, C.B., Katz, M.J., Ambrose, A.F. and Lipton, R.B.: Epidemiology of gait disorders in community-residing older adults, JAGS, 54, 255-261, (2006).

20) 安村誠司：高齢者の転倒と骨折. 眞野行生（編）：高齢者 の転倒とその対策, 40-45, 医歯薬出版, (1999).

21) Kennedy, T.E. and Coppard, L.C.: The prevention of falls in later life: A report of the Kellogg International Work Group on the prevention of falls by the elderly, Danish Medical Bulletin, 34(supplement 4), 1-24, (1987).

22) 林泰史：転倒による骨折, Geriat Med, 29, 681-684, (1991).

23) 安村誠司, 柴田博: 大腿骨頸部骨折とリハビリテーション 一転倒と老人骨折, 臨床リハ, 2, 707-710, 1993. 
24) Grisso, J.A., Kelsey, J.L., et al.: Risk factors for falls as a cause of hip fracture in women, N Eng J Med, 324, 1326-1331, (1991).

25）木村博光, 五十嵐三都男, 他 : 高齢者の大腿骨頸部内側 骨折の予後, 整形・災害外科, 23, 267-274, (1980).

26) 立入克敏, 勝又星郎, 他: 合併症からみた老人大腿骨頸 部骨折の予後, 整形・災害外科, 27, 385-391, (1984).

27) 神藤佳孝, 田中森男, 他：高齢者の大腿骨頸部骨折の 予後因子と予後不良例の検討, 日関外誌, 10, 95-103, (1991).

28) 菊池忠志, 松本真一, 他: 大腿骨頸部骨折後における歩 行能力について, 整形外科, 43, 1879-1883, (1992).

29) 松林孝王, 井上哲郎, 他 : 大腿骨頸部骨折患者の生命予 後について，整形・災害外科, 33, 1387-1391, (1990).

30) Sattin, R.W., Huber, D.A., et al.: The incidence of fall injury events among the elderly in a defined population, Am J Epidemiol, 131, 1028-1037, (1990).

31) 厚生省大臣官房統計情報部：人口動態統計, 厚生統計協 会, 216-217, (1980).

32) 厚生省大臣官房統計情報部：人口動態統計, 厚生統計協 会, 216-217, (1989).

33）厚生省大臣官房統計情報部：人口動態統計, 厚生統計協 会, 308-309, (1997).

34）眞野行生：高齢者の転倒とその対策, 医歯薬出版, 2-7, (1999).

35) Sorock, G.S., Labiner, D.M., et al.: Peripheral neuromuscular dysfunction and falls in an elderly cohort, Am J Epidemiol, 136, 584-591, (1992).

36) Nevitt, M.C., Cummings, S.R., et al.: Risk factors for injurious falls, A prospective study, J Gerontol, 46, M164-M170, (1991).

37) Whipple, R.H., Wolfson, L.I., et al.: The relationship of knee and ankle weakness to falls in nursing home residents, An isokinetic study, J Am Geriatr Soc, 35, 13-20, (1987).

38) Studenski, S., Duncan, P.W., et al.: Postural response and effector factors in persons with unexplained falls, Results and methodologic issues, J Am Geriatr Soc, 39, 229-234, (1991).

39) Campbell, A.J., Borrie, M.J., et al.: Risk factors for falls in a community-based prospective study of people 70 years and older, J Gerontol, 44, M112-117, (1989).

40) Buchner, D.M., Larson, E.B., et al.: Falls and fractures in patients with Alzheimer-type dementia, JAMA, 257, 1492-1495, (1987).

41) Tinetti, M.E.: Factors associated with serious injury during falls by ambulatory nursing home residents, J Am Geriatr Soc, 35, 644-648, (1987).

42) Rubenstein, L.Z., Josephson, K.R.: Interventions to reduce the multifactorial risks for falling, (ed by Masdeu JC, et al.),
Gait disorders of aging, Falls and therapeutic strategies, Lippincott-Raven, 309-326, (1997).

43) Gabell, A., Simons, M.A. and Nayak, U.S.L.: Falls in the healthy elderly, Predisposing causes, Ergonomics, 28, 965-975, (1985).

44) Nashner, L.M.: Adapting reflexes controlling the human posture, Exp Brain Res, 26, 59-72, (1976).

45) Woollacott, M.H. and Nashner, L.M.: Inhibition of the Achilles tendon reflex by antagonist long latency postural responses in humans, Exp Neurol, 75, 420-439, (1982).

46) Diener, H.C., Dichgans, J., et al.: Early stabilization of human posture after a sudden disturbance, Influence of rate and amplitude of displacement, Exp Brain Res, 56, 126-134, (1984).

47) Kosnik, W., Winslow, L., et al.: Visual changes in daily life throughout adulthood, J Gerontol, 43, 63-70, (1988).

48) Sloane, P.D., Baloh, R.W., et al.: The vestibular system in the elderly, Clinical implications, Am J Otolaryngol, 10, 422-429, (1989).

49) Nelson, R.C. and Amin MA.: Falls in the elderly, Emergency Medicine Clinics of North America, 8, 309-324, (1990).

50) Perell, K.L., Nelson, A., Goldman, R.L., Luther, S.L., Prieto-Lewis, N, and Rubenstein, L.Z.: Fall risk assessment measures: an analytic review, J Gerontol A Biol Sci Med Sci, 56, 761-766, (2001).

51) Horak, F.B., et al.: Components of postural dyscontrol in elderly, A review, Neurobiology of Aging, 10, 727-738, (1989).

52）島田裕之, 大㴊修一, 加倉井周一, 内山靖：施設利用 高齢者のバランス機能と転倒との関係, 総合リハ, 28, 961-966, (2000).

53) You, J.Y., Chou, Y.L., Lin C.J. and Su, F.C.: Effect of slip on movement of body center of mass relative to base of support, Clinical Biomechanics, 16, 167-173, (2001).

54) Tang, P.F. and Woollacott, M.H.: Phase-dependent modulation of proximal and distal postural responses to slips in young and older adults, J Gerontol, 54A, M89-M102. (1999).

55) Tang, P.F., Woollacott, M.H. and Chong, R.K.Y.: Control of reactive balance adjustments in perturbed human walking, Roles of proximal and distal postural muscle activity, Exp Brain Res, 119, 141-152, (1998).

56) Owings, T.M., Pavol, M.J., Foley, K.T. and Grabiner, M.D.: Measures of postural stability are not predictors of recovery from large postural disturbances in healthy older adults, $\mathrm{J}$ Am Geriatr Soc, 48, 42-50, (2000).

57) Shimada, H., Obuchi, S., Kamide, N., Shiba, Y., Okamoto, M. and Kakurai, S.: Relationship with the dynamic balance function during standing and walking, Am J Phys Med 
Rehab, 82, 511-516, (2003).

58) Tang, P.F. and Woollacott, M.H.: Inefficient postural responses to unexpected slips during walking in older adults, J Gerontol, 53A, M471-M480, (1998).

59) 大㴊修一, 小島基永, 柴喜崇, 島田裕之, 鈴木隆雄: 地 域在住高齢者を対象とした転倒刺激付きトレッドミルトレ 一ニングのバランス機能改善効果, 無作為化比較対照試 験, 日老医誌, 41, 321-327, (2004).

60) Shimada, H., Obuchi, S., Furuna, T. and Suzuki, T.: A new intervention program for preventing falls among frail elderly people, The effects of perturbed walking exercise using a bilateral separated treadmill, Am J Phys Med Rehab, 83, 493-499, (2004).

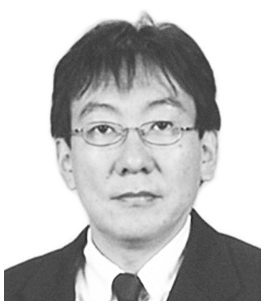

古名 丈人（ふるな たけと） 1986 年札幌医科大学衛生短期大学卒 (理学療法士). 東京都老人医療セン ター理学療法科を経て, 1991 年東京都 老人総合研究所運動機能部門助手 (後 に研究員)。2002 年, 同疫学・福祉・ 政策研究グループ研究員. 2005 年 1 月 より札幌医科大学保健医療学部理学療法学科講師. 専門は, 高齢者理学療法, 運動学, 老年学. 研究テーマは, 高齢者 の運動機能と健康. および介護予防の方法論.

島田 裕之（しまだ ひろゆき）

2003 年北里大学大学院博士課程卒. 東京都老人総合研究所 研究員, Prince of Wales Medical Research Institute 客員研究員 を経て, 現在, 日本学術振興会特別研究員 (東京都老人総合 研究所所属). 高齢者の健康増進に関する研究を行い, とくに 高齢者の転倒予防についての業績が豊富. 